\title{
ISOLATION OF CANDIDA ALBICANS FROM NATURALLY INFECTED FRESHWATER FISH
}

\author{
Mohamed M.A. Zayed ${ }^{1}$, Magdy K. Soliman ${ }^{2}$, Riad H. Kalil. ${ }^{3}$, Talaat T. Saad ${ }^{4}$ \\ ${ }^{1}$ Animal health research inistitute,Kafrelsheikh branch. \\ ${ }^{2}$ Department of Poultry and Fish Diseases, Faculty of Veterinary Medicine, \\ Alexandria University (Damanhour Branch), Egypt. \\ ${ }^{3}$ Department of Poultry and Fish Diseases, Faculty of Veterinary Medicine, \\ Alexandria University, Egypt. \\ ${ }^{4}$ Department of Poultry and Fish Diseases, Faculty of Veterinary Medicine, \\ Alexandria University, Egypt.
}

\begin{abstract}
Fungal diseases considered emerging diseases affecting freshwater fish. In this study, Candida albicans was isolated from diseased Oreochromis niloticus, Cyprinus carpio, Clarius garipinous and Mugil cephalus from fish farms at Behara and Kafrelsheikh provinces. Experimental infection were performed to determine the LD50 in Oreochromis niloticus. Serum chemistry, blood picture and histopathological examination of diseased fish also, discussed.
\end{abstract}

\section{INTRODUCTION}

The fungal diseases of fish cause severe losses among different fish species especially Tilapia nilotica, Common carp and Mugil these species of fishes considered as the most distributed fish species among Egyptian fish farms (El-Shaboury, 1998). Also, these two species accepted by Egyptian consumers and play an important economic role in fish industry in Egypt.

Due to increasing problems occurred by mycotic diseases, this work conducted for: 
1- Isolation and identification of Candida albicans from suspected naturally infected fish.

2- Evaluation of the drastic effect of isolated Candida albicans in fish health status upon experimental infection.

\section{MATERIAL AND METHODS}

\section{A) Materials:}

\section{1- Naturally infected Fish:}

A total number of 80 fish (40 Oreochromis niloticus, 10 Common Carp (Cyprinus carpio L), 20 Catfish (Clarias gariepinus) and 10 (Mugil cephalus) were collected from fish farms at Behera, Kafr El-Sheikh and Alexandria Provinces. The collected fishes showed the clinical signs of different diseases.

The collected fishes were transported alive to laboratory of Poultry and Fish diseases Dep. Faculty of Veterinary Medicine, Alexandria University in large plastic bags filled with oxygen and water, where they were subjected to clinical and microbiological examinations.

\section{2- Fish for experimental infection:}

A total number of $160(50 \pm 5 \mathrm{~g} \mathrm{B.W.})$ apparently healthy fish sample (Oreochromis niloticus) were collected alive from Barseek Fish Farm at Behera governorate. Where the collected fish were transported alive to the laboratory of the Dept. of Poultry and Fish Diseases, Faculty of Veterinary Medicine, Alexandria University in large plastic bags filled with water supplemented with oxygen. 


\section{3- Aquaria:}

Fish were kept in prepared glass aquaria $(100$ X 50 X $30 \mathrm{~cm})$. These aquaria were used for holding the experimental fish throughout the period of the present study (4 weeks), supplied with chlorine free tap water according to (Innes, 1966). The continuous aeration was maintained in each aquarium using an electric air pump. Water temperature was kept at $22 \pm 1 \mathrm{C}$. Fish were acclimatized for 2 weeks prior to the experiment.

\section{4- Feeding:}

Fish were fed on a commercial fish diet containing $25 \%$ crude protein, as described by Eurell et al. (1978). The daily amount of food was offered on two occasions over the day. (at 9 AM and 12 PM). At an initial rate of $3 \%$ of total body weight.

\section{5- Media used:}

\section{A. Media used for isolation of Candida albicans}

- Specific media for Candida albicans (Saborouds dextrose agar)\& (Corn meal agar)(Corn meal tween 80 media).

\section{B. Media used for identification of C. albicans}

Sugar fermentation media ( $1 \%$ glucose, sucrose, lactose, galactose, mannitol in peptone water with $1 \%$ bromocresol purple indicator).

The above-mentioned media were prepared according to (Cruickshank et al., 1975).Gram's stain (Cruickshank et al., 1975).

\section{6- Kits for clinico-biochemical determination}

Kits for glucose, cholesterol, Alkaline phosphates, Liver enzymes (ALT, AST), total protein and serum albumin (Pasteur, Lab, France). 
B) Methods:

\section{1- Clinical and macroscopic examination of naturally infected fish}

Collected fish were examined for clinical signs, pathological lesions according to Amlacher (1970) and Lucky (1977).

\section{2- Mycological examination}

\section{Primary isolation of Candida albicans:}

Isolation from different organs of infected fish on Sabouroud's dextrose agar was incubated for 48-72 hrs at $25 \mathrm{C}$, The suspected colonies were selected and cultivated on Corn meal agar. Inoculated plates were incubated at $25 \mathrm{C}$ for 48-72 hrs(Amlacher, 1970).

\section{3- Characterization of pure isolates}

The pure isolates were characterized morphologically, growth appearance, and biochemically according to Larone (1981). This was done microscopically. A wet films were prepared from the tested isolates. The films were stained with Gram's stain and examined microscopically for staining reaction, shape and arrangement, capsule production ,... etc. The colonial morphology on different media (SD, Corn meal) either solid or liquid were recorded.

C. Biochemical identification was done according to Larone (1981).

\section{4- Lethal dose fifty $\left(\mathrm{LD}_{50}\right)$ determination}

$\mathrm{LD}_{50}$ was determined according to Reed and Munch (1938). The isolate was sub-cultured on Sabouraud dextrose agar and incubated at 2528C for 48-72 hr. The culture centrifuged and supernatant decanted out. The sediment were suspended in sterile saline and standardized for the optical density of McFarland standard No. 2, (each $\mathrm{ml}$ contain approximately $10^{6}$ cell) 


\section{Experimental design of $\mathrm{LD}_{50}$ :}

The fish were divided into seven groups every one contained ten fish. The first sex groups were injected I/P with $0.2 \mathrm{ml}$ of different dilutions of C. albicans. The last group were injected with $0.2 \mathrm{ml}$ of normal saline and used as a control as shown in (Table 1).

The clinical signs and PM lesions recorded daily for one week. $C$. albicans was reisolated from freshly dead fish for verification of deaths.

\section{5- Hematological examination:}

Blood samples were collected one-week post infection from the caudal vessels using disposable tuberculin syringe for the following:-

\section{a) Hematological picture.}

Which include white blood cell (WBCs), red blood cell (RBCs), hemoglobin $(\mathrm{Hb})$, packed cells volume (PCV \%) and differential leucocytic count (DLC), phagocytic assay using citrated blood in the ratio of $0.1 \mathrm{ml}$ of $4 \%$ Sod. citrate solution to $1 \mathrm{ml}$ of blood.

\section{b) Serum separation:}

Was done for Clinico-biochemical determination according to (Lied et al., 1975) and used for examination of glucose, total protein, albumin, globulin and albumin / globulin ratio).

\section{c) Differential leucocytic count:}

Blood films were prepared from collected blood samples according the method described by Lucky (1977). A drop of citrated blood was distributed on glass slide, left until dryness, fixed by methyl alcohol for 3- 
5 min. and stained with Giemsa's solution for 20 minutes. Rinsed under slow water current and dried between filter paper then examined by oil immersion lens. The percentage for each type of cells were calculated according to Schalm (1986).

\section{6- Serum biochemical analysis:}

The activity of serum alanine aminotransferase (ALT) and serum aspartate aminotransferase (AST) was determined and Serum Alkaline phosphatase was determined.

Serum glucose and Serum cholesterol was determined according toTrinder (1969)

Serum total protein, albumin and globulin was determined according toDomuas et al. (1981), Reinhold (1953) and (Coles, 1974) respectively.

\section{7- Histopathological examination:}

Tissue specimens were immediately fixed in $10 \%$ neutral buffered formalin, and then dehydrated, in ascending grades ethyl alcohol. Samples were cleared in three changes of xylol, and then were impregnated in paraffin wax cubes sectioned 4 - $5 \mu$ thickness. Sections were mounted on slides and stained with haematoxylin and eosin.

\section{8- Statistical analysis:}

The data were statistically analyzed using t-test, Duncan-test after ANOVA and simple correlation according to (SAS, 1987). After that, the results presented in the form of figures according to Harvard graphics 4computer program. 


\section{RESULTS}

\section{1- Results of clinical signs and Post-mortem lesions of naturally infected fish:}

The clinical signs of fish, which proved to be positive for $\boldsymbol{C}$. albicanis, were in the form of erosion with congestion of external surface. These signs however did not appear in all cases. Hemorrhages on the body surfaces and operculum with inflamed vent or darkening of skin as well as bilateral exophthalmia and some fish showed eye opacity were also observed (Fig. $1 \& 2$ ).

Post-mortem examinations revealed the presence of enlarged dark spleen, enlarged and congested kidneys, while liver was pale or congested with congestion of all internal organs plus presence of the bloody fluid in the abdomen. (Fig. 3)

\section{2-Results of isolation and identification of $C$. albicans a- Identification of the isolate:}

Attempts to isolate $\boldsymbol{C}$. albicans from different organs (skin, liver, spleen, kidney, gills and intestine) gave 9 isolates that grow on Sabouroud dextrose agar medium, which gave creamy yellowish colonies (table 2\&3).

Morphology: Gram +ve rounded or oval budding or non budding thin walled organism (Fig 4), pseudomycellia which vary in length. On sabouroud agar the colonies are white soft and smooth. On Corn meal tween 80 media produce characteristic chlamedospores.Germ tubes appear as filaments that are notconstricted at their point of origin on the parent cell Fig (4). 


\section{b- Results of biochemical tests:}

The biochemical characterization of the isolates summarized in table (4).

\section{Determination of lethal dose fifty $\left(\mathrm{LD}_{50}\right)$ :}

Results of determination of LD50of C. albicans were summarized in Table (5). The obtained results showed that the $\mathrm{LD}_{50}$ of $C$. albicans were $10^{5}$ in $O$. niloticus.

\section{Results of blood parameters:}

The effect of $\boldsymbol{C}$. albicans infection on cellular components of the blood among $O$. niloticus were presented in Table (7 and 8) it was clear that the reading values of WBCs in O. niloticus. It is worthy to be noted that the WBCs count is slightly increased in the control group than $C$. albicans infected groups. The value of WBCs in infected groups increased.

The values of RBCs, $\mathrm{Hb}$ and $\mathrm{PCV}$ are scientifically closely related to each other but in the present work this fact are different. The RBCs, $\mathrm{Hb}$ and $\mathrm{PCV}$ values in $\mathrm{C}$. albicans infected groups was lower than that of the control group, respectively.

\section{Serum biochemical examination:}

\section{ALT, AST, ALP, glucose and cholesterol Concentrations was presented in table 9:}

The data revealed that the ALT, AST and Alkaline phosphatase levels increased progressively. In addition, the serum glucose was increased and serum Cholesterol concentration increased. 


\section{Serum protein:}

There were decrease in the levels of serum proteins (total proteins, albumin, globulin and albumin/globulin ratio) in the groups infected with the $\boldsymbol{C}$. albicans in $\boldsymbol{O}$. niloticus as observed in table 10 .

Fungal isolation was made from dead, scarified fish, and proved that the $\boldsymbol{C}$. albicans was the cause of death through biochemical reaction.

\section{DISCUSSION}

Fungi causes a various problems among cultured freshwater fish in Egypt [Refaiet al 1987; Manal Adel, 1988; and Salem et al, 1989].

In the present work, some of the naturally infected captured fish showed the following clinical signs: respiratory manifestations typified by rapid opercular movement, swimming near surface of water, gasping of atmospheric air, haemorrhagic patches scattered over the body especially at the base of pectoral and dorsal fins, uni- or bilateral exophthalmia, dark discolouration of skin with or without detachment of scales and sometimes button- like ulcers on the area of caudal peduncle. Autopsies revealed pale or even congested gills, clear or blood stained copious ascites, necrosis of liver, distension of gall bladder and congested spleen or kidneys. Isolation of fungi and/or yeasts could not be incriminated as the only causative agent at this stage of study. However, later on, the results of experiment where the fish were experimentally infected with an isolate of C.albicans may support the previous clinical and postmortem findings observed in naturally infected fish. Furthermore, the findings in experimental and natural infections may also be supported by those of Olufemi and Roberts (1986), and Refaiet al. (1987). 
Mycological examination of diseased and apparently healthy Tilapia catfish, mugil and common carp revealed the recognition of a total of 9 isolates. Isolates were categorized as C.albicans and supported by microbiological and biochemical characters according to (Lennette et al., 1980).

These isolates were obtained from 80 fish (40 Oreochromis niloticus, 10 Common Carp (Cyprinus carpio L), 20 Catfish (Clarias gariepinus) and 10 (Mugil cephalus) mugils . Fungal isolates were found in both apparently healthy and clinically sick fish.

These findings may be supported by the statement of Shaheen (1986) who considered most fungal isolates were normal mycotic flora of freshwater fishes. Manal Ade1 (1988), and Salem et al . (1989) were also able to isolate yeast species from (gills, eyes, heart, liver, gall bladder, spleen, kidney and intestine) of both apparently healthy and diseased fish. Penici1lium was among the isolates from skin of common carp who considered it as a saprophyte.

C.albicans was found to be more prevalent in diseased fish than apparently healthy fish. Isolation of yeast species from internal organs may be supported by Olufemi et al. (1983) who isolated both C.albicans and $C$. parahemolyticus from liver and heart of diseased tilapia.

Yeasts were isolated from different internal organs with a high incidence of isolation from diseased than apparently healthy fish .Yeast mycosis in freshwater fish occupies only a narrow zone in comparison to other diseases. Few reports appear in literature describing certain yeasts as fish pathogens. Probably C. albicans, C. neoformans, Rhodotorulla marina, Rh. glutinis and Torulopsis were the major causative agents (Easa, 1979; Faisal et al .. 1986; Marzouk et. al. . 1990; and Shahcen, 1991). 
In the present. study, C.albicans were isolated at a high incidenee from skin of examined fish species. Faisal et a1, (1986), Marzouk et al (1990); and Shahecn (1991) incriminated Rh. marina and Rh. qlutinis as a cause of some problems in fish as eye affections tail and fin rot in tilapia, Common carp and catfish . Cryptpcoccus sp. were isolated with low incidence ( 3 isolates from gills of catfish and one isolate from liver of mugils). Finding of this organism may be supported by the reports of Faisal et al. (1986), Marzouk et al. (1990), and Shaheen, (1991) who isolated Cr.difflucns , $\mathrm{Cr}$. albidus .Cr.Inurenti and Cr. neoformans from skin and gills of tilapia, catfish, common carp.

The clinical signs and P.M. lesions includes erosion of jaws with congestion, hemorrhage and inflammation with darkening of body color and enlarged, congested spleen and kidney.

There was congestion of all internal organs. These symptoms attributed mainly to C.albicans infection. Dimenna (1954).

Trails for isolation of C.albicans from different organs were made and we successfully isolate 9 isolates grow on specific media.

Biochemically it were oxidase, ureas and indole negative, while, positive with glucose and maltose.

According to the morphological and biochemical characters of the isolates, we identified it as C.albicans especially the presence of germination (germ test tube) which appeared in microscopic examination horse serum infected with fungus. Results of biochemical tests were similar to these reported by other investigators including Dimenna (1954). 
The Mortality pattern and $\mathrm{LD}_{50}$ and the acute infection was carried out by injection of different concentration of C.albicans. $\mathrm{LD}_{50}$ in $O$. niloticus was $\left(10^{5}\right)$.

Jacobsohn and Rosado (1962) reported that there was a high mortality percentage among the experimentally infected fish under different stress conditions. These conditions are overcrowdness, external parasitism and transportation with mortality rates of $83 \%, 70 \%$ and 60 $\%$ respectively in $O$. niloticus and all of these stress conditions facilitated the infection with C.albicans.

In $O$. niloticus there was erosion of tail fin and hemorrhagic spots of body surface with exophthalmia, congestion with ascitis of abdominal region with congestion of internal organs especially in liver and kidney. These clinical signs \& P.M. lesions mainly due to infection of $C$. albicanis and its endotoxin which affecting body of fish, these observation are partially similar to those reported by Clark and Wallace (1975).

Histopathlogically infected fish gills showed, cellular proliferation, goblet cells, hyperplesia with necrosis with diffused mild oedematus changes with eosinphilic granular cell infiltration. Hepatopancrease with hydropic degeneration with cytoplasmic vacculation.Kidney with hyaline eosinophilic masses with hyaline degeneration. Spleen showed enlargement of melanomacrophage center and dark brown melanophore with melanin pigment.

These results may be due to septaecemic infection of C. albicans. Marked depletion of haemopiotic elements were evident in the spleen and kidney, Kockova-Kratochvilova (1987) were detected the similar changes. 
The blood parameters as total leucocytic counts and differential leucocytic counts have diagnostic importance and usually readily respond to identical factors as physical chemical and biological stressors (Kligman (1975) andSoliman, 1996).

The haematological examination of the blood of O.niloticus indicated decrease in $\mathrm{RBCs}$ and $\mathrm{Hb}$ concentration decreased progressively

The causes of decreasing RBCs, Hb and PCV may be attributed to dried damage of small blood capillaries and decline in serum cholesterol (Lu (1977), liver damage that leads to instability of RBCs with increasing formation of immature RBCs (Levine., 1979), necrosis and destruction of haematopiotic organs (Kidney and spleen) (Vogel, 1974) and retention of splenic elepsoids which leads to significant correlation between increase of splenic weight of diseased fish and its content of $\mathrm{Hb}$ which indicate the stress effect of C.albicans.

Similar results recorded that the decrease in $\mathrm{RBCs}, \mathrm{Hb}$ concentration which appeared in treated fish in relation to control fish and a accompanied by thrombocytopenia due to decreasing the number of blood platelets and this mainly attributed to stress condition that associated with C.albicans infection, also due to destruction of liver, kidney, spleen (Haematobiotic organs) preventing haematobiosis process (blood synthesis).

The differential leucocytic counts revealed that, the lymphocytes, monocytes, basophiles and eosinophils count decreased in O.niloticus. Also, neutrophils count, increased progressively. The differential leucocytic counts in C.albicans infection (Stress condition) revealed lymphopenia, monocytopenia, eosinopenia which associated usually with Kafrelsheikh Vet. Med. J. Vol. 14 No. 1 (2016) 
acute stages of haemolyticanaemia (Zaorsha and Zagrodski (1985), which was confirmed histopathologically by destructive action on liver, kidney, spleen, gills (Yamacuchi (1983) Confirmed these results histologically by presence of vacuolated liver with necrosis, activated melanomacrophage center of spleen, decreased haematobiotic elements, tubular and degeneration, injury of renal blood vessels.

C.albicans infection faces great resistance from body defense to overcome the infection, also due to destructive action on liver, kidney and spleen and other haematobotic organs as well as defense mechanism and finally leucocytopenia occurs (Zenitani (1974).

The enzymatic examination revealed that the GPT, GOT level and Alkaline phosphatase level increased in infected O.niloticus.

The significant increase of AST, ALT and ALP enzymes was mainly due to anticonvulsant activity and also due to increase in alkaline phosphatase activity which leads to hepatocytic destruction and unbalanced metabolism (Gupta and Chatterjee, 1980). Also, increase in serum transaminases (ALT and AST), may reflect the myocardial and hepatic damage leading to extensive liberation of the enzymes into blood circulation (Seyfakth (1982). and Fuchs et al., 1986). Moreover, serum ALT and AST activities are considered as a sensitive indicator to evaluate hepatocelular and myocardial damage (Seyfakth (1982).

Concerning the Glucose and Cholesterol concentrations the serum glucose level increased

The increasing level in serum glucose and cholesterol level attributed to the destruction of hepatocytes which act as a main store of glycogen leading to glycogenosis that cause increase in the amount of serum glucose (Wlckerham and Andreason (1972). 
The significant increase in cholesterol level due to decrease in kidney and liver function metabolism. The serum proteins were useful in diagnosis of fish diseases. The results indicated that albumin, globulin, total protein levels decreased in O.niloticus.

Hypoalbuminemia, hypoglobulinemia and hypoprotenameia which observed may be attributed to stress condition (C.albicans infection) causing liver damage that causing decrease in serum proteins concentration (Edvington et al., 1994) indicated that al fish under stress have greatest decrease in total protein.

The A/G ratio were slightly increased with C.albicans infection due to the decrease in albumin lower than that of globulin.(Khalil, 1998).

Our experiment showed that there was a decrease in serum globulin in C.albicans infection and this decrease which may be attributed to lymphopenia (Reiersol, 1988) and this due to liver damage where all plasma protein synthesis usually occurs in liver except gamma globulins which produced by lymphocytes . Moreover, the decrease in protein and globulin can explain the drastic effect of C.albicans infection on immune response of infected fish with subsequently increased the drastic damage effects of C.albicans.

Reiersol (1988) reported that liver disorder is usually accompanied by hypoalbuminaemia. Both hypoglobulinaemia and hypoalbuminaemia confirmed the recorded hypoproteinaemia, which was associated with liver damage, also indicated that the fish under stresses had hypoalbuminaemia.

The causes of decreased serum total protein due to vascular damage leading to increasing permeability due to histamine release (Tanner 1975), liver damage and anorexia, Non specific proteolysis. 
Mohamed M.A. Zayed et., al.

Table (1): Showing the experimental design of $\mathrm{LD}_{50}$

\begin{tabular}{|c||c||c||}
\hline \multicolumn{1}{|c||}{ Group } & C. albicans dilution & Number of O. niloticus \\
\hline \hline 1 & $10^{-1}$ & 10 \\
\hline 2 & $10^{-2}$ & 10 \\
\hline 3 & $10^{-3}$ & 10 \\
\hline 4 & $10^{-4}$ & 10 \\
\hline 5 & $10^{-5}$ & 10 \\
\hline 6 & $10^{-6}$ & 10 \\
\hline 7 & Control saline & 10 \\
\hline
\end{tabular}

Table (2): Results of the fungal examination of the naturally infected fish samples

\begin{tabular}{|c|c|c|c|}
\hline \multirow{2}{*}{ Samples Fish species } & \multirow{2}{*}{ No. of examined samples } & \multicolumn{2}{|c|}{ +ve samples for C.albicans } \\
\hline & & No. & $\%$ \\
\hline Tilapia & 40 & 4 & $10 \%$ \\
\hline Carp & 10 & 2 & $20 \%$ \\
\hline Catfish & 20 & 2 & $10 \%$ \\
\hline Mugil & 10 & 1 & $10 \%$ \\
\hline Total & 80 & 9 & $11 \%$ \\
\hline
\end{tabular}

Table (3): C.albicans isolated from different organs of fish

\begin{tabular}{|c|c|c|c|c|c|c|}
\hline \multirow{3}{*}{ Fish species } & \multirow{3}{*}{ No. } & \multicolumn{5}{|c|}{ Site of isolation of C.albicans } \\
\hline & & intestine & liver & spleen & kidney & skin \\
\hline & & No. & No. & No. & No. & No. \\
\hline O.niloticus & 4 & 1 & 1 & 0 & 0 & 2 \\
\hline C.carp & 2 & 1 & 1 & 0 & 0 & 0 \\
\hline Catfish & 2 & 0 & 0 & 0 & 1 & 1 \\
\hline Mugilcephalus & 1 & 0 & 0 & 0 & 1 & 0 \\
\hline
\end{tabular}

Kafrelsheikh Vet. Med. J. Vol. 14 No. 1 (2016) 
Isolation Of Candida Albicans From Naturally ...

Table (4): Biochemical characters of isolated C.albicans

\begin{tabular}{|l||c||}
\hline \multicolumn{1}{|c||}{ Characters } & C. albicans \\
\hline \hline Production of pseudo-mycelia on rice agar & + \\
\hline Urease test & - \\
\hline Sugar fermentation & + +) \\
\hline Galactose & + \\
\hline Glucose & - \\
\hline Lactose & + \\
\hline Maltose & - \\
\hline Sacrose & + \\
\hline Sugar assimilation & + \\
\hline Galactose & - \\
\hline Glucose & + \\
\hline Lactose & + \\
\hline Maltose & + \\
\hline Sacrose & + \\
\hline Nitrate assimilation & + \\
\hline Production of Chlamydo-spores on corn meal agar & + \\
\hline Growth at 35C & + \\
\hline \hline
\end{tabular}

Table (5): Differential tests for Candida species

\begin{tabular}{|c||c||c||c|}
\hline Species & $\begin{array}{c}\text { Growth on Sabouraud } \\
\text { actidions agar }\end{array}$ & $\begin{array}{c}\text { Growth on Sabouraud } \\
\text { tetrazolium agar }\end{array}$ & $\begin{array}{c}\text { Surface film on Sabouraud } \\
\text { dextrose broth }\end{array}$ \\
\hline \hline C. albicans & $+\mathrm{ve}$ & White & $-\mathrm{ve}$ \\
\hline
\end{tabular}

Table (6): $\mathrm{LD}_{50 \text { of }}$. albicans in O.niloticus.

\begin{tabular}{|c|c||}
\hline Conc. of $\boldsymbol{C}$. albicans & Mortality ratio of $\boldsymbol{O}$. niloticus \\
\hline \hline $10^{-1}$ & $9 / 10$ \\
\hline $10^{-2}$ & $8 / 10$ \\
\hline $10^{-3}$ & $8 / 10$ \\
\hline $10^{-4}$ & $7 / 10$ \\
\hline $10^{-5}$ & $\mathbf{5 / 1 0}$ \\
\hline $10^{-6}$ & $3 / 10$ \\
\hline control & $0 / 10$ \\
\hline
\end{tabular}

The $\mathrm{LD}_{50}$ in $O$. niloticus is $10^{-5}$

Kafrelsheikh Vet. Med. J. Vol. 14 No. 1 (2016) 
Mohamed M.A. Zayed et., al.

Table (7): Differential leucocytic counts of $O$. niloticus at one-week post infection.

\begin{tabular}{||c||c||c||c||c||c||}
\hline Treatment & Lymphocyte & Monocyte & Basophils & Eosinophils & Neutrophils \\
\hline \hline \multirow{2}{*}{ C. albicans } & $\mathrm{b}$ & $\mathrm{a}$ & $\mathrm{a}$ & $\mathrm{b}$ & $\mathrm{a}$ \\
& $58.67 \pm 0.33$ & $1.43 \pm 0.33$ & $8.67 \pm 0.33$ & $10.00 \pm 0.58$ & $22.23 \pm 1.45$ \\
\hline \multirow{2}{*}{ Control } & $\mathrm{a}$ & $\mathrm{b}$ & $\mathrm{b}$ & $\mathrm{a}$ & $\mathrm{b}$ \\
& $61.67 \pm 2.33$ & $1.67 \pm 0.33$ & $9.00 \pm 0.58$ & $10.60 \pm 0.58$ & $27.67 \pm 1.20$ \\
\hline
\end{tabular}

Values are $($ Mean $\pm \mathrm{S} . \mathrm{E}),(\mathrm{N}=3)$, the same column carrying different letters are significantly different at $(\mathrm{P}<0.01)$.

Table (8): WBCs, RBCs, $\mathrm{HB}$ and $\mathrm{PCV} \%$ of $O$. niloticus at one-week post infection.

\begin{tabular}{|c|c|c|c|c|}
\hline Treatment & WBCs & RBCs & $\mathbf{H b}$ & PCV \\
\hline C. albicans & $\begin{array}{c}\mathrm{b} \\
23.43 \pm 0.33\end{array}$ & $\begin{array}{c}\mathrm{b} \\
2.11 \pm 0.09\end{array}$ & $\begin{array}{c}\mathrm{a} \\
10.33 \pm 0.33\end{array}$ & $\begin{array}{c}\mathrm{a} \\
26.00 \pm 1.15\end{array}$ \\
\hline Control & $\begin{array}{c}\mathrm{a} \\
24.33 \pm 0.88\end{array}$ & $\begin{array}{c}\mathrm{a} \\
2.21 \pm 0.09\end{array}$ & $\begin{array}{c}\mathrm{a} \\
10.73 \pm 0.33\end{array}$ & $\begin{array}{c}\mathrm{b} \\
26.17 \pm 1.20\end{array}$ \\
\hline
\end{tabular}

Values are $($ Mean $\pm \mathrm{S} . \mathrm{E}),(\mathrm{N}=3)$, the same column carrying different letters are significantly different at $(\mathrm{P}<0.01)$.

Table (9): GPT, GOT, Alkaline phosphatase, glucose Cholesterol and level of O. niloticus at one-week post infection.

\begin{tabular}{|c|c|c|c|c|c|}
\hline Treatment & GPT & GOT & Alk. Ph & Glucose & Cholesterol \\
\hline C. albicans & $\begin{array}{c}\mathrm{a} \\
68.67 \pm 4.33\end{array}$ & $\begin{array}{c}\mathrm{a} \\
64.33 \pm 0.33\end{array}$ & $\begin{array}{c}\mathrm{a} \\
16.00 \pm 0.58\end{array}$ & $\begin{array}{c}\mathrm{a} \\
98.00 \pm 4.58\end{array}$ & $\begin{array}{c}\mathrm{a} \\
246.00 \pm 1.00\end{array}$ \\
\hline Control & $\begin{array}{c}b \\
62.67 \pm 1.33\end{array}$ & $\begin{array}{c}\mathrm{a} \\
63.00 \pm 1.15\end{array}$ & $\begin{array}{c}\mathrm{b} \\
15.00 \pm 0.58\end{array}$ & $\begin{array}{c}\mathrm{b} \\
97.00 \pm 9.00\end{array}$ & $\begin{array}{c}\mathrm{b} \\
227.67 \pm 6.33\end{array}$ \\
\hline
\end{tabular}

Values are (Mean $\pm \mathrm{S} . \mathrm{E}),(\mathrm{N}=3)$, the same column carrying different letters are significantly different at $(\mathrm{P}<0.01)$.

Table (10): Serum proteins (Albumin, globulin, total protein and albumin/ globulin ratio) level of $O$. niloticus at one-week post infection.

\begin{tabular}{|c||c||c||c||c|}
\hline Treatment & Albumin & Globulin & Total protein & Albumin / globulin \\
\hline \hline \multirow{2}{*}{ C. albicans } & $\mathrm{a}$ & $\mathrm{a}$ & $\mathrm{a}$ & $\mathrm{a}$ \\
& $3.03 \pm 0.06$ & $2.21 \pm 0.17$ & $5.43 \pm 0.15$ & $1.43 \pm 0.14$ \\
\hline \multirow{2}{*}{ Control } & $\mathrm{b}$ & $\mathrm{b}$ & $\mathrm{b}$ & $\mathrm{a}$ \\
& $3.10 \pm 0.25$ & $2.70 \pm 0.33$ & $5.91 \pm 0.09$ & $1.45 \pm 0.50$ \\
\hline
\end{tabular}

Values are $(M e a n \pm S . E),(N=3)$, the same column carrying different letters are significantly different at $(\mathrm{P}<0.01)$.

Kafrelsheikh Vet. Med. J. Vol. 14 No. 1 (2016) 


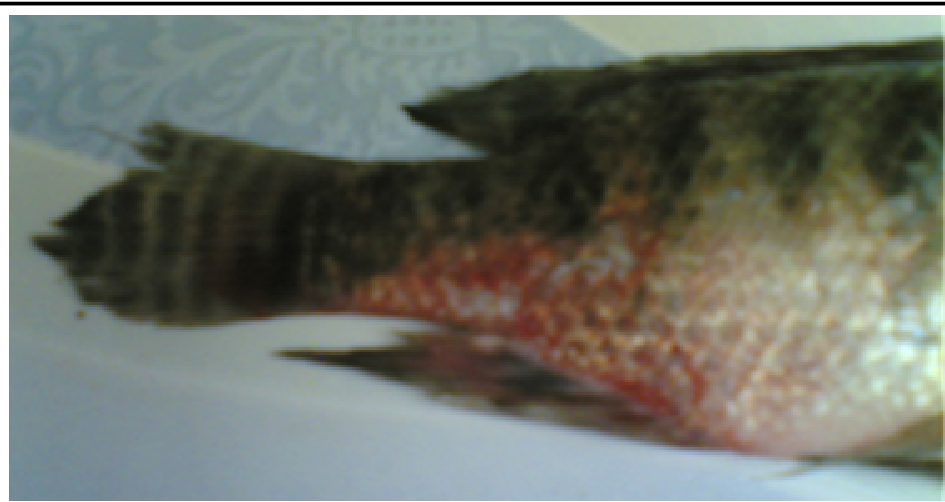

Fig. (1): Haemorrhage in caudal peduncle in O. niloticus infected with $C$. albicans.

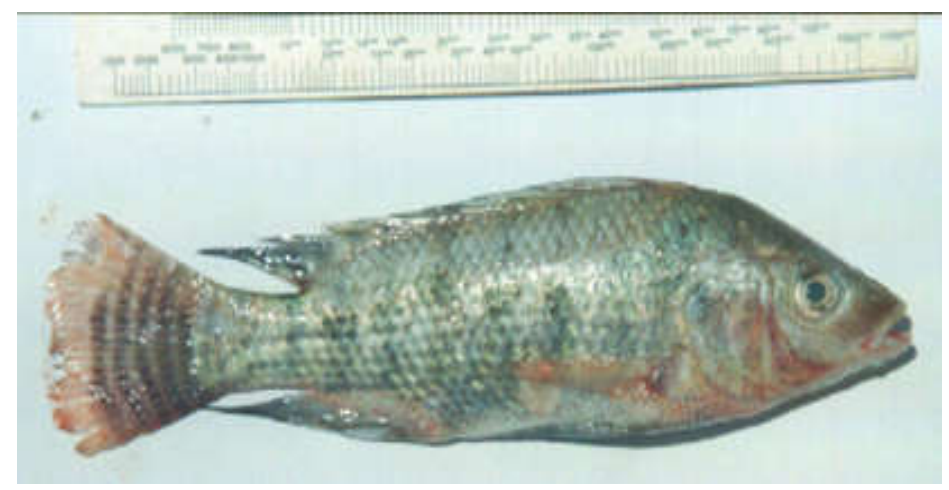

Fig. (2): Tail fin congestion with pectoral fin haemorrhage and haemorrhage of the Isthmus in O. niloticus infected with C. albicans.

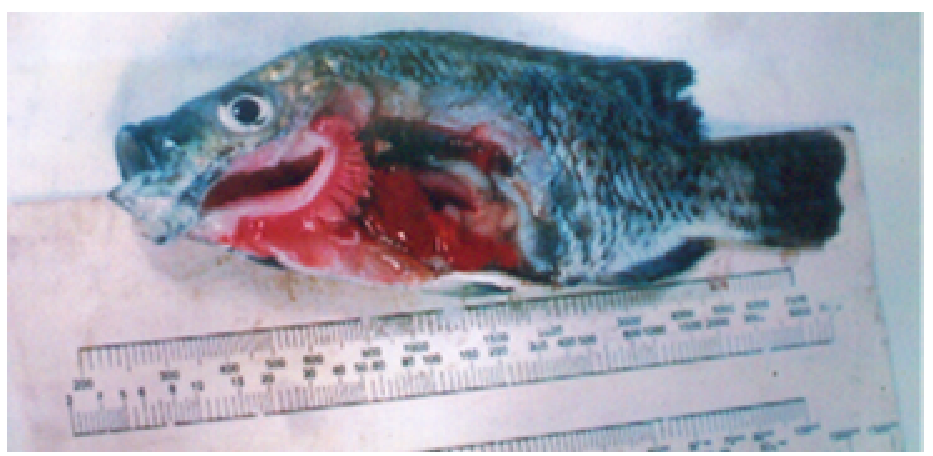

Fig. (3): Highly congested internal organs in $O$. niloticus infected with $C$. albicans. 


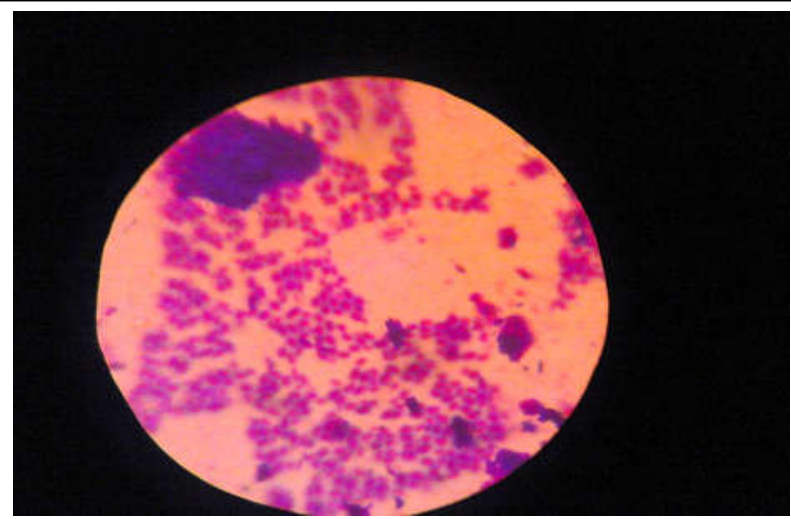

Fig. (4): Yeast (C. albicans ) as Gram positive cocci under microscope.

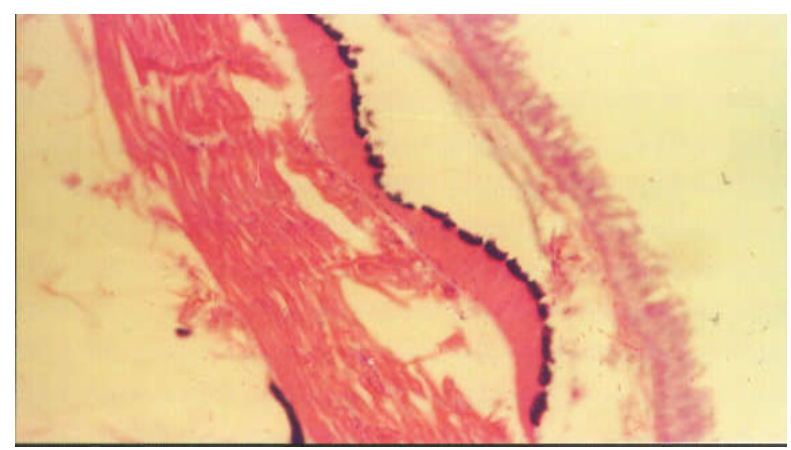

Fig. (5): Skin of $O$. niloticus experimentally infected with $C$.albicans showing excessive melanosis in the dermis with multifocal slight dermal edema. (H\&E, X250)

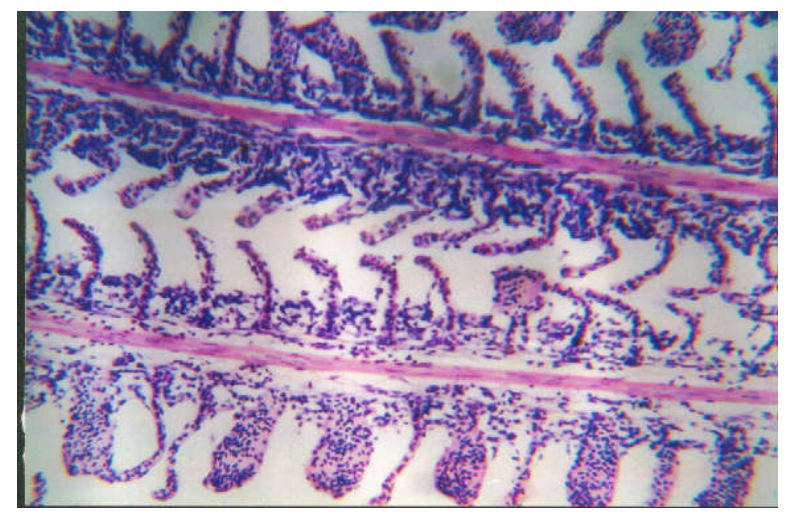

Fig. (6): Gills of tilapia experimentally infected with C.albicans showing lamellar telangectasis with subepithelial edema. (H\&E, X160). 


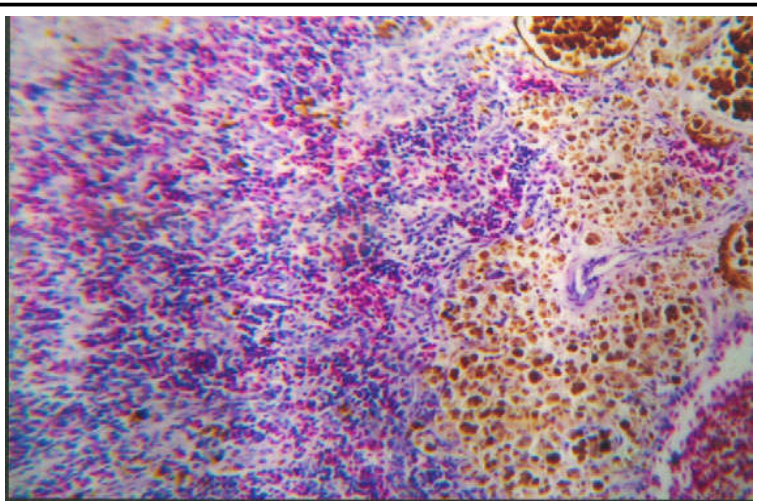

Fig. (7): Spleen of O. niloticus experimentally infected with C.albicans showing hyperactivation of melanomacrophage center. (H\&E, X250).

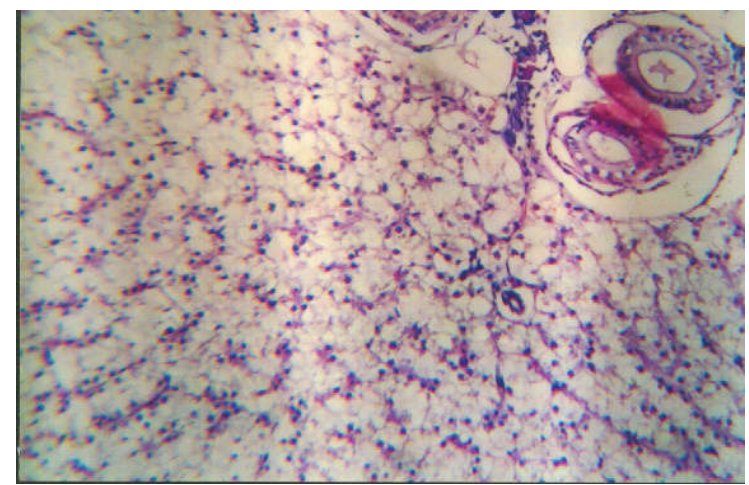

Fig. (8): Hepatopancrease of $O$. niloticus experimentally infected with C.albicans at $2^{\text {nd }} \mathrm{wk}$. showingdifuse moderate fatty vaculation of the hepatocytes. (H\&E, X160).

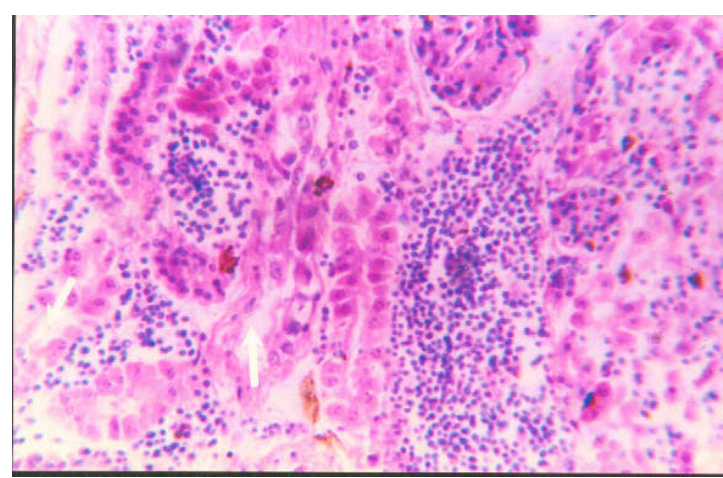

Fig. (9): Posterior kidney of O.niloticus tilapia experimentally infected with C.albicans. showing tubular necrosis. (H\&E, X250). 


\section{REFERENCES}

- Amlacher, E. (1970): Textbook of fish diseases, T.E.S puplication, Jersy. USA, P.117-135.

- Clark, D.S.; Wallace, R.H.; and Davis, J.J. (1964): Yeasts occurring on apples and in apple cider. Can. J. Microbiol.,1,145-149.

- Coles, E.H. (1974): Veterinary clinical pathology. pp.211-213. W.B. Saunders Company, Philadelphia, London, Toront

- Cruickoshank, R.; Uguid, j.; Marmion, B and Swain, R. (1975): Medical microbiology $12^{\text {th }}$ Ed., Churchill livingstone, Edinburgh, London and Newyork.

- Dimenna, M.E and parle, J.M. (1954): Some extra-human occurrences of pathogenic yeast. proc.Univ. Otago Med. School,32,2.

- Duomas, B.T.; Bayso, D.D.; Carter, R.J.; peters, T. and Schaffer, R. (1981): Determination of total serum protein. Clin. Chem., 27: 16421643.

- Easa, M. El-S. (1979): Role of the fungi s causative agents of gill diseases in carp in some Egyptian fish farms. Ph .D. Thesis, Veterinary Acaderay, Moscow, USSR.

- Edvington, T. S.; Harvey, R. B. and kubena, L. F. (1994): Effect of aflatoxin in growing lambs fed ruminally degradable or escape protein sources. J. Anim. Sci., 72(5): 1274-81.

- Eurell, T.E.; lewis, S. D. H. and Grumbles, E.C. (1978): Comparasion of selected diagnostic tests for isolation of motile Aeromonas septicemia in fish. Am. J. Vet. Res., 39(8): 1384-1386. 
- Faisal, M.; Easa, M.; Torkey, H. and Ellshaboury, F. (1986): Cyptococcosis in cultured Nile perch (latus niloticus). Alex. Vet. Sci., Vol. 2, No. 1.405-417.

- Gupta, M.S. and Chatergee, M. (1980): Effects of Ochratoxin A and Citrinin on liver function and metabolism. IRCS Med., Sci., 7:320.

- Hawk, P.B.; Oscar B. L. andSummerson, W. (1981): Hawk,s histological chemistry. London J. and A. Churchill Ltd. $14^{\text {th }} \mathrm{Ed}$.

- Innes, W.T. (1966): Exotoxic aquarium fishes. $19^{\text {th }}$ Ed. Aquarium in corported, Newjersy, USA.

- Jacobbsohn, K.P. and Rosado, J. M. (1972): Etudes sur la thiaminase des champignons. Compt. Rend. Soc. Boil., 146, 1454-1456.

- Kilgman, A. M. (1975): Aids in the technic in the identification of candida albicans. J. Invest. Dermatol., 19,173-170.

- Kockova-kratochvilova, A. (1987): Action of boric acid on microorganisms of the genus candida, intern. Tijdschr. Brouw. enMout., 1947,21-23.(Abst. From Chem. Abstr.,43, 7087,1949.

- Larone, D.H.(1987): Medically important fungi, a guide toidentification . $2^{\text {nd }} E d$., Elsevier Science puplishing Co. Inc.

- Levine, H.; Oyaas, J.E.; Wasserman, L.; Hoogerlletde, J.C. and Stern, R.M. (1979): Riboflavin produced by candida yeasts. Ind. Eng. Chem., 41, 1665-1668.

- Lied, E.; Gezerde, Z. and Braskhan, D.R. (1975): Simple and rapid technique for repeated blood sampling in Rinbow trout. J. of Fish Res. Board of Canada, 32(5): 699-701.

- Lu, k.C.; Allen, D.G., and bollen, W.B. (1977): Association of yeasts with the Douglas- fir beetle forrest Sci., 336-343. 
- Luky, Z. (1977): Methods of the diagnosis of fish diseases. Amerind publishing Co. PVTTtd, New Delhi, Bomby, Clcutta and New York.

- Manal Adel (1988): Studies on mycotic infection in freshwater fish. M.V.Sc. Thesis, zagazig Univ.

- Olufemi, B.E. and Roberts, R.J. (1986): Induction of clinical Aspergillomycosis by feeding contaminated diet to tilapia (Oreochromis niloticus). J. fish Dis., 9,123-128.

- Reed, L.J. and Muench, H. (1938): A simple method of estimating fifty percent end points. Am. J. Hyg., 27: 493-497.

- Refai, M.; Abdel halim, M.M.; Afify, M.M.H.; Youssef, H. and Marzouk, M. (1987): Studies on Aspergillomycosis in catfish (Clariaislazerci). Allgerneine pathologic and pathologischeAnalomie, tagung der DeutachenVeterinarMedizinischenGesellgchart der EuropeischengeselIschaft fur Veterinar pathologic, 63, 1-12.

- Reiesol, S. (1988): Occurrence of yeastes in the intestinal tract of 20 patients during treatment with bacitracin and neomycin. Antonie van leeeuwenhoek. J Microbiol. Serol., 24, 23-20.

- Reinhold, R. R. (1953): Determination of serum albumin. Clin. Chem., 21: 1370-1372.

- Reinhold, R. R. (1953): Determination of serum albumin. Clin. Chem., 21: 1370-1372.

- Salem, A.A.; Refai, M.K.; Eissa, I.A.M.; Marzouk, M.; Moustafa, M. and Manal, A. (1986): Microbiological investigations on cultured tilapia in Egypt. Alex J. Vet. Sci., 5 ( 2):625-634.

- Schalm, O.W. (1986): Veterinary haematology. $4^{\text {th }}$ Ed., Lea and febiger, Philadelphia. 
- Seyfakth, W. (1982): Uber das stadium anchondriosomen de soorhefe (Manilla albicans) undihr Nachweismit Tripheyltetra- zoliumchloride. Naturvvissens chaften, 39, 162-163.

- Shaheen, A.A.M. (1991): Studies on yeast in freshwater fish ph.D. Thesis, Faculty of vet. Med., Cairo University.

- Tanner, F.W.J.; Vojnovihch, C. and Vanlann, J.M. (1975): Riboflavin production by candida species. Science, 101, 180-181.

- Trinder, P. (1969): Determination of glucose in blood using glucose oxidase with an alterative oxygen acceptor. Ann. Clin. L.I.N. Biochem. 6,24.

- Vogel, H.A. (1974): The polysaccharides of Candida albicans. Proc. Soc. ExptlBiol. Med.,86,373-375.

- Wickerham, L.J. and Andreason, A.A. (1972): The lyophil process: its use in the preservation of yeasts. Wallerstein labs. Communs, 6, 165-169.

- Wiles, A.E. (1970): Wild yeasts. Brewers Guild J., 36, 141-159.

- Yamacuchi, T.; Toda, H. and Hamada, C. (1983): The manufacture of fodder yeast from wastsuliite liquor. J. Japan. Tech. Assoc. Pulp paper ind., 7, 12-18.

- Zaorsha, H. and Zagrodski, S. (1985): The biological production of fodder yeasts from molasses which has been free from salts. Act Microbiol. Polon., 2, 179-203.

- Zenitani, B. (1974): Yeasts occurring in fishery fermentation products. On the morphological characteristics of asporo-genous yeasts. Sci. bull. Bull. Fac. Agr. Kyushu Univ., 14, 589-594. 